\title{
Path Analysis on the Risk Factors of Sexually Transmitted Disease among Men Who Have Sex with Men Community in Surakarta
}

\author{
Siti Nurhalimah'), Hanung Prasetya'), Bhisma Murti') \\ 1)Masters Program in Public Health, Universitas Sebelas Maret \\ ${ }^{2)}$ School of Health Polytechnics, Ministry of Health Surakarta
}

\begin{abstract}
Background: Men who have sex with men (MSM) have a higher prevalence of HIV and other sexually transmitted infections (STI) than the heterosexual men. The number of STI cases in MSM in Indonesia in 2017 was 4,144. The study aimed to examine risk factors of sexually transmitted disease among MSM community in Surakarta, Central Java.

Subjects and Method: This was a cross sectional study carried out in Surakarta, Central Java, from October to November 2018. A sample of 188 MSM was selected by fixed diseases sampling. The variable dependent was STI. The independent variables were age, education, number of sexual partner, sexual behavior, intention, attitude, perceived behavior control, and subjective norm. The data were collected by questionnaire and analyzed by path analysis.

Results: STI was directly increased by unsafe sexual behavior $(b=2.03$; 95\% CI= 1.15 to 2.91; $\mathrm{p}<0.001)$, older age $(\mathrm{b}=1.83 ; 95 \% \mathrm{CI}=0.58$ to 3.09; $\mathrm{p}=0.004)$, multiple sexual partners $(\mathrm{b}=2.28$; $95 \% \mathrm{CI}=1.33$ to $3.23 ; \mathrm{p}<0.001$ ). It was indirectly affected by intention, attitude, perceived behavior control, subjective norm, and education.

Conclusion: STI is directly increased by sexual behavior, age, multiple sexual partners. It is indirectly affected by intention, attitude, perceived behavior control, subjective norm, and education.
\end{abstract}

Keywords: sexually transmitted infections, sexual behavior, men who have sex with men

\section{Correspondence:}

Siti Nurhalimah. Masters Program in Public Health, Universitas Sebelas Maret. Jl. Ir. Sutami 36A, Surakarta 57126, Central Java, Indonesia. Email: halimah1006.mdf@gmail.com.

Mobile: 082233890866

\section{BACKGROUND}

$\overline{\text { Sexually Transmitted Diseases (STDs) con- }}$ sist of various groups which include bloodborne diseases, sexually transmitted infections and ulcerative lesions. Most sexually transmitted diseases show early symptoms of infection (Aliyeah and Sarah, 2011). Sexually transmitted infections (STIs) refer to a large number of different infections, which are usually transmitted through sexual contact and produce various diseases. STI control includes the availability and quality of medical care, public education on safe sexual relations, access to condom use and other prevention methods, convenient and affordable methods of diagnosis and treatment, emergence of antibiotic resistance, and social stigma associated with STIs (Ghanem and Quinn, 2014).

Gender and sexual minorities experience health inequalities, especially in sexual health, mental health and the use of health substances. Sexual and Gender Minorities (SGM) are those that include individuals with various sexual orientations, physical characteristics, identity and gender expression (Blondeel et al, 2016). Homosexuality is defined as the behavior of someone who shows sexual relations with someone who has the same gender. In addition, homosexuality can also be interpreted 
as desires which do not necessarily lead to sexual behavior or activity (Henry, 2014).

The Community of Men Sex with Men (MSM) is considered more vulnerable to transmission of sexually transmitted infections (Keshinro et al., 2016). Individuals of gay, bisexual, men who have sex with men, are not proportionally at risk of STIs and account for nearly $50 \%$ of those who receive HIV care in the UK. This population has complex STI vulnerabilities. The rectal mucosa is unicellular and very susceptible to trauma during receptive anal sex (Aseel and Mark, 2018). This is due to the sexual behavior of the male sex community with men (MSM) who tend to be free and changing partners and low information about reproductive health (Ramadhani et al., 2017).

The World Health Organization (WHO) estimates based on a review of literature data from 2005 to know 2012 among a general population of urogenital infections with chlamydia, gonorrhea and trichomoniasis and reports on national data on syphilis seroprevalence in visitors to antenatal clinics. The data were then standardized and it was found that in 2012, among women aged 15-49 years it was estimated that the global prevalence of chlamydial infection was $4.2 \%$, gonorrhea $0.8 \%$, trichomonas $5 \%$ and syphilis $0.5 \%$. Meanwhile, among men it was estimated that the prevalence of chlamydial infection was $2.7 \%$, gonorrhea $0.6 \%$, trichomoniasis $0.6 \%$ and syphilis amounting to $0.48 \%$. This condition illustrates that an estimated 131 million new cases of chlamydia, 78 million cases of gonorrhea, 143 million cases of trichomoniasis, and 6 million cases of syphilis, where the prevalence rate is estimated to vary depending on geographical area and sex.

The results of the study on 1113 Sex Men with Men (MSM), showed that 15.1\% were positive STIs, $13 \%$ positive rectal STIs, $3.4 \%$ STIs in the bladder tract and $1.2 \%$ positive STIs in the rectal and bladder. Rectal chlamydia is more common than rectal gonorrhea (Mustanski et al., 2016).

STIs are known to trigger and faciletate HIV transmission. The high prevalence of STIs in a population somewhere is an early sign of the risk of the spread of HIV. The prevalence of STIs can validate condom use behavior data obtained from behavioral surveillance. The lack of condom use behavior will be illustrated by the continued high prevalence of STIs (Lutz, 2015). Sexually Transmitted Infectious Bacteria are significant HIV trigger factors among Sex Men with Men (MSM) since the onset of HIV cases. Several cohort studies report that a history of gonorrhea is a risk factor for HIV cases. Rectal STIs have been identified to increase the risk of HIV transmission where the HIV virus attacks the human immune system (Scott et al., 2016).

According to the report of the Directorate General of Disease Prevention and Control of the Ministry of Health of the Republic of Indonesia for the first quarter of 2017, the number of STI cases with diagnosis based on the syndrome approach and laboratory examination according to the risk group was 4.144 MSM, where the figure was the third highest after female sex workers and high risk couples. Report of the integrated survey and biological behavior by the Indonesian Ministry of Health (2015), prevalence of sexually transmitted infections (STIs) in 2015 where the prevalence of gonorrhea in MSM was $12.72 \%$, the prevalence of syphilis in MSM was $15.71 \%$ and the prevalence of chlamydia was as high as MSM $18.53 \%$.

Meanwhile, based on the Central Java Province Central Bureau of Statistics data in 2015, there were 14,302 cases of Sexually Transmitted Infections and 464 cases in 
Surakarta. The results of the preliminary study conducted on June 5, 2018 at the Surakarta Gaya Mahardhika Foundation show that for the population of MSM from January to May 2018, there were 2,340 people with an average of almost 70\% being active STI patients. This figure is a fairly high number of the entire population.

Risky sexual behavior is one of the factors that has a large influence on the increase in the number of sexually transmitted infections (STIs) in the MSM group. STI events are closely related to behavioral changes in MSM communities. Researchers predict risk factors that influence the incidence of sexually transmitted infections (STIs), namely by using Theory of Planned Behavior (TPB). This theory states that behavior is formed because of the influence of one's intentions determined by three concepts, namely attitudes, subjective norms and perceptions of behavioral control (Ajzen, 1991 cite Droomers et al, 2016).

According to Green and Kreuter (2005), health behavior is influenced by individual and environmental factors with the PRECEDE PROCEED behavior change model. Behavior is influenced by 3 main factors, namely: predisposing factors (predisposing factors), enabling factors (reinforcing factors) and reinforcing factors (reinforcing factors). The number of partners and sexual behavior is an enabling factor for the incidence of sexually transmitted infections in the community of men who have sex with men. Education is a reinforcing factor for the incidence of sexually transmitted infections in the community of men who have sex with men.

Based on the explanation above, the researchers are interested in examining the influence of age factors, number of partners and risky sexual behavior, on the incidence of sexually transmitted infections (STIs) in the community of Men who have sex with men (MSM) using the theory of planned behavior (TPB) and the PRECEDE PROCEED model with path analysis, to determine the direct and indirect effects of a risk factor on the incidence of sexually transmitted infections in the community of men who have sex with men in Surakarta.

\section{SUBJECTS AND METHOD}

\section{Study Design}

This was an analytic observational with a cross sectional design. The study was conducted in Surakarta, Central Java, in November 2018.

\section{Population and samples}

The population of this study was MSM community in Surakarta, Central Java. A sample of 188 MSM was selected by fixed diseases sampling, consisting of $47 \mathrm{MSM}$ with STIs and $141 \mathrm{MSM}$ without STIs.

\section{Study Variables}

The dependent variable was sexual transmitted disease. The independent variables were sexual behavior, number of sexual partners, age, education, intention, attitude toward unsafe sexual behavior, subjective norm, and perceived behavioral control.

\section{Operational Definition of Variables}

Sexual behavior was defined as a type of sexual behavior of research subjects who were considered at risk of sexually transmitted infections. This includes the way sexual intercourse, condom use and frequency of sexual intercourse. The more individuals engage in risky sexual behavior, the risk of experiencing STIs will increase. The measurement scale was continous and transformed into a dichotomy for analysis, coded $\mathrm{o}$ for safe sex behavior and 1 for unsafe behavior.

The number of partners was defined as the number of sexually active couples during the last month of the study period. The measurement scale was continuous which was converted into a dichotomy for 
analysis purposes, coded o for single sexual partner and 1 for multiple sexual partners.

Age was defined as length of time from birth to data collection. The measurement scale was continous and transformed into dichotomous, coded $\mathrm{o}$ for aged $<20$ years or $>50$ years and 1 for aged $20-50$ years.

Education was defined as the last formal education attained by study subjects. The measurement scale was categorical, coded o for $\geq$ senior high school and 1 for $<$ senior high school.

Intention was defined as the desire of study subjects to carry out behavior at risk for sexually transmitted infections (STIs), The measurement scale was continous and transformed into dichotomous, coded o for weak and code 1 for strong.

Perceived behaviour control was defined as perceptions of study subjects regarding the ease and difficulty of study subjects for not exposure to unsafe sexual behavior. The measurement scale was continous and transformed into dichotomous, coded o for strong and 1 for weak.

Subjective norm was defined as perception or opinion of study subjects about the rules or standards that exist in the social environment aboutun safe sexual behavior at risk of sexually transmitted infection. The measurement scale was continous and transformed into dichotomous, coded o for strong and code 1 for weak.

Attitude was defined as study subject's response in the form of a positive or negative assessment of the risky sexual behavior of sexually transmitted infections in MSM community. The measurement scale was continous and transformed into dichotomous, coded o for negative and 1 for positive.

Sexually transmitted infection was defined as the status of sexually transmitted infections. The measurement scale was categorical, coded o for yes and 1 for no.

\section{Study Instruments}

The data were collected by questionnaire that has been tested for the validity and reliability. The reliability test was carried out with Alpha Cronbah test on 30 study subjects.

\section{Data Analysis}

The results of the characteristics analysis of the research subjects and univariate analysis in the form of categorical / dichotomous data were described in frequency (n) and percent (\%). Bivariate analysis was performed using the Chi-Square test. Multivariate analysis used path analysis, through the following stages:
a. Model spesification
b. Model identification
c. Model suitability
d. Estimation
e. Model respesification

\section{Research Ethics}

The research ethics was obtained from the Ethical Research Committee, Faculty of MEdicine, Universitas Sebelas Maret Surakarta, Central Java. The research ethics include informed consent, anonymity, and confidentiality.

\begin{tabular}{l}
\hline RESULTS \\
\hline 1. Sample characteristics \\
Table 1 showed sample characteristics. \\
Table 1 showed that most of the study \\
subjects were aged 20-50 years (82\%), had \\
education $\geq$ Senior high school (63.3\%), \\
positive attitude (62.3\%), and strong \\
subjective norm.
\end{tabular}

As many as $56 \%$ study subjects experienced unsafe sexual behavior. As many as $53 \%$ study subjects had single sexual partner. As many as $50.5 \%$ study subjects had weak intention. 
Table 1. Sample characteristics

\begin{tabular}{|c|c|c|}
\hline Characteristics & $\mathbf{n}$ & $\%$ \\
\hline \multicolumn{3}{|l|}{ Age } \\
\hline$<20$ years $/>50$ years & 34 & 18 \\
\hline 20-50 years & 154 & 82 \\
\hline \multicolumn{3}{|l|}{ Education } \\
\hline$<$ Senior high school & 69 & 36.7 \\
\hline$\geq$ Senior high school & 119 & $63 \cdot 3$ \\
\hline \multicolumn{3}{|l|}{ Sexual Behavior } \\
\hline Unsafe & 105 & 56 \\
\hline Safe & 83 & 44 \\
\hline \multicolumn{3}{|c|}{ The number of partners } \\
\hline Single & 100 & 53 \\
\hline$\geq 3$ partners & 88 & 47 \\
\hline \multicolumn{3}{|l|}{ Intention } \\
\hline Weak & 95 & 50.5 \\
\hline Strong & 93 & 49.5 \\
\hline \multicolumn{3}{|l|}{ Attitude } \\
\hline Negative & 71 & 37.7 \\
\hline Positive & 117 & 62.3 \\
\hline \multicolumn{3}{|l|}{$\begin{array}{l}\text { Perceived behavior } \\
\text { control }\end{array}$} \\
\hline Strong & 95 & 50.5 \\
\hline Weak & 93 & 49.5 \\
\hline \multicolumn{3}{|l|}{ Subjective Norms } \\
\hline Strong & 124 & 66 \\
\hline Weak & 64 & 34 \\
\hline \multicolumn{3}{|l|}{ STIs } \\
\hline Yes & 47 & 25 \\
\hline No & 141 & 75 \\
\hline
\end{tabular}

\section{Bivariate Analysis}

Table 2 showed the results of bivariate analysis. Table 2 showed that age $<20$ or $>50$ years old $(\mathrm{OR}=2.90 ; 95 \% \mathrm{CI}=0.96$ to 8.73; $\mathrm{p}=0.004)$, education $<$ senior high school (OR= 3.20; 95\% CI= 1.62 to $6.29 ; \mathrm{p}=$ o.001), unsafe sexual behaviour (OR= 7.64; $95 \% \mathrm{CI}=3.49$ to $16.70 ; \mathrm{p}<0.001)$, multiple sexual partners $(\mathrm{OR}=7.68 ; 95 \% \mathrm{CI}=3.43$ to 17.17; $\mathrm{p}<0.001)$, strong intention toward unsafe sex behavior $(\mathrm{OR}=2.61$; $95 \% \mathrm{CI}=$ 1.44 to $4.73 ; \mathrm{p}=0.001)$, negative attitude $(\mathrm{OR}=2.10 ; 95 \% \mathrm{CI}=1.15$ to $3.85 ; \mathrm{p}=0.001)$, weak perceived behaviour control $(\mathrm{OR}=$ 2.59; $95 \% \mathrm{CI}=1.44$ to $4.67 ; \mathrm{p}=0.001)$, and weak subjective norm $(\mathrm{OR}=2.73$; 95\% $\mathrm{CI}=$
1.45 to $5.11 ; p=0.001)$ increased the risk of STI.

\section{Path Analysis}

Figure 1 depicted path diagram on the determinants of STI. The observed variables were 9, the endogenous variables were 4 , the exogenous variables were 5 , and the parameters were 9. The number of degree of freedom was 27 (over-identified). Table 3 showed the results of path analysis.

Table 3 showed that STI was directly increased by age $(b=2.03$; $95 \% \mathrm{CI}=1.15$ to 2.91; $\mathrm{p}<0.001$ ). Study subject aged $20-50$ years old had the logodd to experience STI was 1.83 units higher than study subjects aged $<20$ or $>50$ years old $(b=1.83 ; 95 \%$ $\mathrm{CI}=0.58$ to 3.09 ; $\mathrm{p}=0.004$ ).

STI was directly increased by number of sexual partners. Multiple sexual partners increased the risk of STI with logodd 2.28 units $(b=2.28 ; 95 \% \quad C I=1.33$ to 3.23 ; $\mathrm{p}<0.001$ ).

STI was directly increased by unsafe sexual behavior. Unsafe sexual behavior increased the risk of STI by logodd 2.03 units higher than safe sexual behavior $(\mathrm{b}=$ 2.03; $95 \% \mathrm{CI}=1.15$ to $2.91 ; \mathrm{p}<0.001)$.

STI was indirectly affected by intention, attitude, perceived behavior control, subjective norm, and education.

Intention increased with perceived behavior control $(b=0.79$; 95\% $\mathrm{CI}=0.17 \mathrm{up}$ to $1.42 ; \mathrm{p}=0.012)$, attitude $(\mathrm{b}=0.65 ; 95 \%$ $\mathrm{CI}=0.02$ to $1.28 ; \mathrm{p}=0.042)$, subjective norm $(b=0.67 ; 95 \% \mathrm{CI}=0.004$ to $1.34 ; \mathrm{p}=$ o.048)

Unsafe sexual behaviour increased with intention $(b=0.71 ; 95 \% \mathrm{CI}=0.08$ to 1.35; $\mathrm{p}=0.027)$ and subjective norm $(\mathrm{b}=$ 1.54; $95 \% \mathrm{CI}=1.87$ to $2.22 ; \mathrm{p}<0.001)$.

Attitude increased with education $(\mathrm{b}=$ 1.16; $95 \% \mathrm{CI}=0.48$ to $1.83 ; \mathrm{p}=0.001$ ). 
Journal of Health Promotion and Behavior (2018), 3(3): 199-211

https://doi.org/10.26911/thejhpb.2018.03.03.07

Table 2. The result of bivariate analysis

\begin{tabular}{|c|c|c|c|c|c|c|c|}
\hline \multirow{3}{*}{ Independent Variables } & \multicolumn{4}{|c|}{ STI } & \multirow{3}{*}{ OR } & \multirow{3}{*}{ CI 95\% } & \multirow{3}{*}{$\mathbf{p}$} \\
\hline & \multicolumn{2}{|c|}{ Yes } & \multicolumn{2}{|c|}{ No } & & & \\
\hline & $\mathbf{n}$ & $\%$ & $\mathbf{n}$ & $\%$ & & & \\
\hline \multicolumn{8}{|l|}{ Age } \\
\hline$<20$ or $>50$ years old & 4 & 11.7 & 30 & 88.3 & 2.90 & $0.96-8.73$ & 0.004 \\
\hline 20-50 years old & 43 & 27.5 & 111 & 72.5 & & & \\
\hline \multicolumn{8}{|l|}{ Education } \\
\hline$<$ Senior high school & 34 & 49.3 & 35 & 50.7 & 3.20 & $1.62-6.29$ & 0.001 \\
\hline$\geq$ Senior high school & 13 & 10.9 & 106 & 89.1 & & & \\
\hline \multicolumn{8}{|l|}{ Number of sex partner } \\
\hline 1-2 people & 9 & 9 & 91 & 91 & 7.68 & $3.43-17.17$ & $<0.001$ \\
\hline$\geq 3$ people & 38 & 43.2 & 50 & 56.8 & & & \\
\hline \multicolumn{8}{|l|}{ Sexual behavior } \\
\hline Not risky & 10 & 9.5 & 95 & 90.5 & 7.64 & $3.49-16.70$ & $<0.001$ \\
\hline Risky & 37 & 44.5 & 46 & $55 \cdot 5$ & & & \\
\hline \multicolumn{8}{|l|}{ Intention } \\
\hline Weak & 9 & 9.5 & 86 & 90.5 & 2.61 & $1.44-4.73$ & 0.001 \\
\hline Strong & 38 & 40.9 & 55 & 59.1 & & & \\
\hline \multicolumn{8}{|l|}{ Attitude } \\
\hline Negative & 11 & $15 \cdot 5$ & 60 & 84.5 & 2.10 & $1.15-3.85$ & 0.001 \\
\hline Positive & 36 & 30.8 & 81 & 69.2 & & & \\
\hline \multicolumn{8}{|l|}{ PBC } \\
\hline Strong & 11 & 11.6 & 84 & 88.4 & 2.59 & $1.44-4.67$ & 0.001 \\
\hline Weak & 36 & 38.7 & 57 & 61.3 & & & \\
\hline \multicolumn{8}{|l|}{ Subjective norm } \\
\hline Strong & 5 & 4 & 119 & 96 & 2.73 & $1.45-5.11$ & 0.001 \\
\hline Weak & 42 & 65.6 & 22 & 34.4 & & & \\
\hline
\end{tabular}

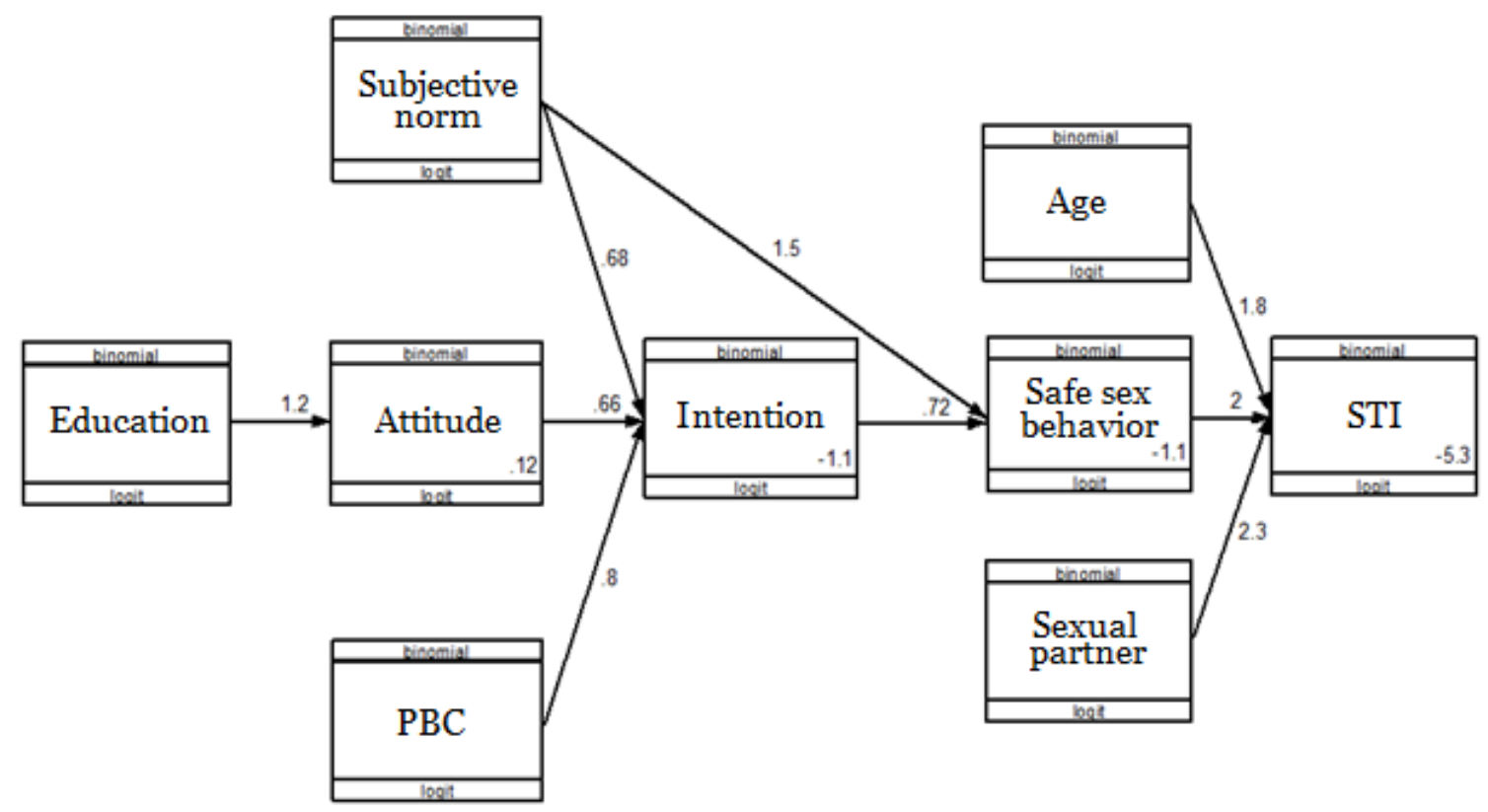

Figure 1. The result of path analysis model 
Table 3. The result of path analysis

\begin{tabular}{|c|c|c|c|c|c|c|}
\hline \multirow{2}{*}{$\begin{array}{c}\text { Dependent } \\
\text { Variables }\end{array}$} & & \multirow[b]{2}{*}{ Independent Variables } & \multirow[b]{2}{*}{$\mathbf{b}$} & \multicolumn{2}{|c|}{ CI 95\% } & \multirow[b]{2}{*}{$\mathbf{p}$} \\
\hline & & & & $\begin{array}{c}\text { Lower } \\
\text { Limit }\end{array}$ & $\begin{array}{l}\text { Upper } \\
\text { Limit }\end{array}$ & \\
\hline \multicolumn{7}{|l|}{ Direct effect } \\
\hline \multirow[t]{3}{*}{ STI } & $\leftarrow$ & Age & 1.83 & 0.58 & 3.09 & 0.004 \\
\hline & $\leftarrow$ & $\begin{array}{l}\text { The number of sexual } \\
\text { partner }\end{array}$ & 2.28 & 1.33 & 3.23 & $<0.001$ \\
\hline & $\leftarrow$ & Sexual behavior & 2.03 & 1.15 & 2.91 & $<0.001$ \\
\hline \multicolumn{7}{|l|}{ Indirect effect } \\
\hline \multirow[t]{2}{*}{ Sexual behavior } & $\leftarrow$ & Intention & 0.71 & 0.08 & 1.35 & 0.027 \\
\hline & $\leftarrow$ & Subjective norm & 1.54 & 0.87 & 2.22 & $<0.001$ \\
\hline \multirow[t]{3}{*}{ Intention } & $\leftarrow$ & Attitude & 0.65 & 0.02 & 1.28 & 0.042 \\
\hline & $\leftarrow$ & Subjective norm & 0.67 & 0.004 & 1.34 & 0.048 \\
\hline & $\leftarrow$ & $\mathrm{PBC}$ & 0.79 & 0.17 & 1.42 & 0.012 \\
\hline Attitude & $\leftarrow$ & Education & 1.16 & 0.48 & 1.83 & 0.001 \\
\hline \multicolumn{7}{|c|}{$\mathrm{N}$ observation $=188$} \\
\hline \multicolumn{7}{|c|}{ Log likelihood= -423.22} \\
\hline
\end{tabular}

$\frac{\text { DISCUSSIONS }}{\text { 1. The effect of age on STI }}$

The result of this study showed that research subject aged 20-50 years old were more likely to have the incidence of Sexually Transmitted Disease (STD). Age was important to note, because the younger the age of a person, the more at risk of contracting an STD. Ages 20-40 years old were a high risk group for the incidence of STD (Daili, 2017). Age was one of the important variables in influencing a person's activities so that in doing sexual activities, more mature people have better considerations compared to younger ones (teenagers). The age of late adolescents was susceptible to be contracted by STD because they generally have a greater number of sex partners and have a tendency to change partners (Azwar, 2000 in Jois, 2015). According to the Indonesian Ministry of Health (2013), populations aged 15-49 years old were included in the estimated data and projections of HIV prevalence from the AEM (Asean Epidemic Model) module which designed to explain the dynamics of HIV epidemics in Asian countries or certain geographical locations, indicating that in the age range, it was susceptible to HIV and STD incidents. Similarly, the results of several previous surveys indicated that younger age tends to be more at risk of contracting STD and HIV (STBP, 2007). This was in line with Hirshfield (2008) who stated that in the age group 1839 years old, people were more likely to have STD by 2 times compared to the age $>$ 40 years old.

\section{The effect of numbers of sexual partner on STI}

The result of this study showed thatthe number of partner $\geq 3$ people were more likely to experience STD. The partner in this case was the number of study subjects' partners who were sexually active for a period of approximately one month. Individuals with more partners tend to be more at risk of experiencing STD (Daili, 2017). MSM groups were more vulnerable because of the transmission of STD or sexually transmitted disease (Keshinro et al., 2016). This was due to the sexual behavior of the community of men who have sex with men (MSM) who tend to be free and have 
Journal of Health Promotion and Behavior (2018), 3(3): 199-211

https://doi.org/10.26911/thejhpb.2018.03.03.07

multiple partners and also have low information about reproductive health (Ramadhani et al., 2017).

\section{The effect of sexual behavior on STI}

The result of this study showed that unsafe sexual behavior can increase the risk of having an STD. The population of MSM has complex STD vulnerabilities. The rectal mucosa was unicellular and very vulnerable to trauma caused by friction during receptive anal sex (Aseel and Mark, 2018). Anal sex can cause injury to the tissue so that the virus can enter the body through injured tissue (Kalina et al., 2009). Oral sex and anal sex behavior done by MSM communities in sexual activities were very risky for STD incidents (Henry, 2014). The results of this study were in line with a study done by Noviyani (2017) which stated that there was a relationship between MSM sexual behavior and STD incident.

\section{The effect of intention on STI}

The result of this study showed that there was an effect of intention on the incidence of STD through sexual behavior. Strong intention to engage in sexual behavior would increase the risk of STD. Intention was one of the constructs of the Theory of Planned Behavior (Ajzen, 2015). Intention would be a behavior under will control. Willing control was a person's ability to decide to do or not to do a behavior (Abamecha, Godesso, Girma 2013). Intention to behave was a construct that showed a person's psychological readiness to perform a behavior. The stronger the intention, the more likely the behavior was done (Conner and Armitage, 1998; Ajzen, 2016; University of Twente, 2018 in Murti, 2018)

\section{The effect of subjective norm on STI through unsafe sexual beha- vior}

The result of this study showed that there was an effect of subjective norm on the incidence of STD through sexual behavior. Weak subjective norms would increase individuals to engage in risky sexual behavior so that it can increase the risk of having an STD. In the Planned Behavior,the subjective norm was the perception or opinion of individuals about the rules or standards that exist in the social environment, especially those who were considered important or influential by the individual (Murti, 2018). The community and the social environment of the respondents rejected the presence of risky sexual behavior which in this case was the relationship of same gender, if the subjective norms of the respondents were weak, the respondents would continue to engage in risky sexual behavior even though the community has banned it. The result of this study was also supported by Matthew (2015) which stated that subjective norms and normative beliefs became factors that influenced the behavior changes in individuals.

\section{The effect of attitude on STI through intention}

The result of this study showed that there was an effect of attitude on the incidence of STD through intention. Attitude was a predisposition to the action of a behavior. Attitudes were divided into two, namely positive attitudes and negative attitudes. A positive attitude means the tendency of actions to approach, like, and expect certain objects. Negative attitude mean indicated by a tendency to stay away from, avoid, hate, and dislike certain objects (Wood, 2000 in Murti, 2018). The positive attitude of the study subject to risky sexual behavior would increase the intention of the research subjects to engage in risky sexual behavior. Most of the respondents in this study had a positive attitude towards sexual behavior. The results of this study were supported by Alexandra et al. (2018) who stated that 
individual attitude influenced behavioral changes.

\section{The effect of subjective norm on STI through intention}

The result of this study showed that there was an effect of subjective norm on the incidence of STD through intention. Study subjects who have weak subjective norm would increase their intention to behave sexually, thereby increasing their risk of experiencing STD. The result of this study was supported by the Theory of Planned Behavior (Ajzen, 2015) where in the model chart of this theory showed that individual subjective norms affected the behavior of the individual indirectly through intention. In addition, the result of this study was also supported by Alexandra et al. (2018) who stated that subjective norms influenced the change of behavior in individuals, in this case the subjective norms of respondents influenced them to refuse or engage in risky sexual behavior.

\section{The effect of perceived behavioral control on STD through intention}

The result of this study showed that there was an effect of perceived behavioral control on the incidence of STD through intention. Perceived behavioral control was a person's perception of the ease or difficulty of doing behavior, including the confidence of an individual to do or not do a behavior (Murti, 2018). Ajzen (1991) in Theory of Planned Behavior stated that the construct of perceived behavioral control actually came from the concept of Bandura which called self-efficacy. In this study, the perceived of behavioral control was interpreted as the respondent's self-confidence to not engage in risky sexual behavior so that weak perceived behavioral control of the study subjects would increase their intention to engage in sexual behavior which caused STD. The result of this study was supported by Alexandra et al. (2018) who stated that perceived behavioral control affected changes in individual behavior, as well as the individual's sexual behavior.

9. The Effect of Education on the Incidence of STD through Attitude

The result of this study showed that there was an effect of education on the incidence of STD through attitude. Study subjects with low education tend to have limited knowledge regarding the dangers of STD and reproductive health. Most of the study subjects who experienced STD came from low level of education. Attitude was a predisposition or tendency of a person to respond and assess an object of attitude (Murti, 2018). Education was related to a person's ability to receive and respond to information. Low education would lead to inappropriate assessment of unsafe sexual behavior. The result of this study was supported by Jois (2015) who stated that education affected the incidence of STD. The lower the education, the higher the risk of STD.

\section{REFERENCES}

Abamecha F, Ameyu G, Eshetu G (2013). Intention to Voluntary HIV Counseling and Testing (VCT) among Health Professionals in Jimma Zone, Ethiopia: The Theory of Planned Behavior (TPB) Perspective. BMC Public Health 13(1). https://doi.org/10.1186/1471-2458-13-140.

Ada WCL, Siddharth S, Ka Hing W, Susanna KPL, Patrick CYW (2015). Epidemiology of sexually transmitted viral hepatitis in human immunodeficiency virus positive men who have sex with men in Asia. Journal of the Formosan Medical Association. 114(12): 11541161. https://doi.org/10.1016/j.jfma.2015.08.008. 
Journal of Health Promotion and Behavior (2018), 3(3): 199-211

https://doi.org/10.26911/thejhpb.2018.03.03.07

Aliyeah A, Sarah MH (2011). Sexually transmitted diseases. 253-265. https://doi.org/10.1016/j.osfp.2011.06.003

Andrew BJ, Mullan BA, de Wit JB, Monds LA, Todd J, Kothe EJ (2016). Does the theory of planned behaviour explain condom use behaviour among men who have sex with men? A metaanalytic review of the literature. AIDS Behav. 20(12): 2834-2844. Doi: 10.1007/s10461-016-1314-0

Aseel H, Mark P (2018). LGBT Sexual Health. Medicine. 46(5): 300-303.

Azwar S (2013). Sikap manusia dan teori pengukurannya. Edisi 2. Yogyakarta: Pustaka Pelajar.

Barmpagianni E, Travlos A, Kalokairinou A, Sachlas A, Zyga S (2013). Investigation of aggravating od psychosocial factors on health and predictability of smooking and alcohol use in post adolescent student. Health Psychology Research. 1(2): 15. Doi: 10.4081/hpr.2013.e15.

Berman SM, Cohen MS (2006). STD Treatment: How can it Improve HIV Prevention in The South? Sex Transm Dis.33:S50-7

Blondeel K, Say L, Chou D, Toskin I, Khosla R, Scolaro E, Temmerman M (2016). Evidence and knowledge gaps on the disease burden in sexual and gender minorities: a review of systematic reviews. Int J Equity Health. 22(15): 16. doi: 10.1186/s12939-016-0304-1.

Cara ER, Courtney M, Karen S, Fields, Melissa E, Stephanie T, Abigail NT (2016). Beyond anal sex: sexual practices of men who have sex with men and associations with HIV and other sexually transmitted infections. The Journal of Sexual Medicine, 13(3): 374-382. https://doi.org/10.1016/j.jsxm.2016.01.001.
Charles K (2017). Lesbian, gay, bisexual, and transgender (LGBT) Survivorship. Seminars in Oncology Nursing, 34(1): 52-59. https://doi.org/10.1016/j.soncn.2017.12.002.

Christine MP (2015). Revisiting PRECEDE-PROCEED: A leading model for ecological and ethical health promotion. Health Education Journal 1-12. Doi: 10.1177/0017896915619645.

Dany N (2017). Perilaku seksual berisiko infeksi menular seksual (IMS) pada kelompok lesbi di Kota Semarang. Journal of Health, 2(2). http://journal.unnes.ac.id/sju/index.php/jhealthedu/.

Demartoto A (2012). Pengetahuan, sikap dan perilaku seksual laki-laki yang berhubungan seks dengan laki-laki (LSL) dalam Kaitannya dengan HIV dan AIDS. http://argyo.staff.uns.ac.id/2012/12/15/pengetahuan-sikapdan-perilaku-seksual-laki-laki-yangberhubungan-seks-dengan-laki-lakilsl-dalam-kaitannya-dengan-hiv-danaids/ diakses pada 10 Juni 2018

(2010). Mengerti, memahami dan menerima fenomena homoseksualitas. Semarang: Universitas Diponegoro

(2013). Orientasi seksual dan perilaku seksual. http://argyo.staff.uns.ac.id/2013/05/21/orientasi-seksualdan-perilaku-seksual/ diakses Juni 2018.

Direktorat Jendral P2 \& PL Kemenkes RI (2016). Statistik Kasus HIV/AIDS di Indonesia per Desember 2016. Jakarta: Ditjen P2 \& PL Kemenkes RI.

Direktorat Jenderal Pengendalian Penyalit dan Penyehatan Lingkungan (2015). Surveilans terpadu biologis dan perilaku. Jakarta: Kementrian Kesehatan RI. 
Eduardo E V, Elizabeth AD, Jeffrey DS, Alexandra $\mathrm{O}$ and Thomas P (2016). Sexually transmitted disease diagnoses among Hispanic immigrant and migrant men who have sex with men in the United States. International Journal of STD \& AIDS. 1-8. Doi: 10.1177/0956462415610679.

Edelman EJ, Christopher AC, Wanda R, Nicholas B, Heidi J, Marjorie SR (2016). Stigma, substance use and sexual risk behaviors among HIVinfected men who have sex with men: A qualitative study. Preventive Medicine Reports, 3: 296-302. https://doi.org/10.1016/j.pmedr.2016.03.012

Epton T, Norman P, Harris P, Webb T, Snowsill FA, Sheeran P (2014). Development of Theory-Based HealthMessages: Three-Phase Programme of Formative Research. Health Promotion International. 30(3). Doi: 10.1093/heapro/dauoo5.

Frankis J, Goodall L, Clutterbuck D, Abubakari R, Flowers P (2017). Regular STI testing amongst men who have sex with men and use social media is suboptimal - a cross-sectional study. Int J STD AIDS. 28(6): 573-583. doi: 10.1177/0956462416636780.

Galvin SR, Cohen MS (2004). The Role of sexually transmitted diseases in HIV Transmission. Nat Rev Microbiol. 3342.

Green LW, Kreuter MW (2005). Health program planning: An educational and ecological approach. 4th edition. NY: McGraw-Hill Higher Education.

Hawari D (2009). Pendekatan psikorelegi pada homoseksual. Jakarta: Balai Penerbit FKUI

Henry JC (2014). Sexual transmitted infections in men who have sex with men. Clinics in Dermatology, 32(2): 181-
188. https://doi.org/10.1016/j.clindermatol.2013.08.001.

Hirshfield S, Wolitski RJ, Chiasson MA, Remien RH, Humberstone M, Wong $\mathrm{T}$ (2008). Screening for depressive symptoms in an online sample of men who have sex with men. AIDS care, 20(8): 904-910.

Hohman ZP, Crano WD, Siegel JT, Alvaro EM (2014). Attitude ambivalence, friend norms and adolescent drug use. Prev Sci. 15(1): 65-74. Doi: 10.007/s11121-013-0368-8.

Ajzen IPAM, Lange AW, Kruglanski, Higgins (2012). The Theory of Planned Behavior. Handbook of theories of social psycholog. 1: 438-459. London, UK: Sage.

Ajzen I (2015). Consumer attitudes and behavior: the theory of planned behavior applied to food consumption decisions. Rivista di Economia Agraria, Anno LXX. 121-138. Doi: 10.13128/REA-18003.

Irianto K (2010). Memahami Seksologi. Bandung: Sinar Baru Algensindo.

John MS (2013). Non-HIV sexually transmitted infections. Obstetrics, Gynaecology \& Reproductive Medicine. 23(6): 180-184. https://doi.org/10.1016/j.ogrm.2013.03.011.

John RB (2017). Sexual minority in conflict zones. Aggression and Violent Behavior, 35: 33-37. https://doi.org/10.1016/j.avb.2017.06.006.

Jois N, Zahroh S, Priyadi N (2015). Analisis faktor-faktor yang berhubungan dengan kejadian IMS pada remaja di klinik IMS Puskesmas Rijali dan Passo Kota Ambon. Jurnal Promosi Kesehatan Indonesia. 10(02).

Jun-Jie X, Yan-Qiu Y, Qing-Hai H, HongJing Yan, et al. (2017). Treatmentseeking behaviour and barriers to service access for sexually transmitted 
diseases among men who have sex with men in China: a multicentre cross-sectional survey. Infectius Disease of Poverty. doi: 10.1186/s40249016-0219-5.

Kalina O, et al. (2009). Psychological and behavioural factors associated with sexual risk behaviour among slovak students. BMC Publich Health Journal. 9: 15 .

Karen G, Barbara K, Rimer K, Viswanath (2008). Health behavior and health education: theory, research, and practice. ISBN 978-0-7879-9614-7.

Kartono, Kartini (2009). Psikologi abnormal dan abnormalitas seksual. Bandung: CV Mandar Maju.

Kementerian Kesehatan RI (2012). Aku bangga aku tahu. Jakarta: Pusat Promosi Kesehatan Kementerian Kesehatan RI

(2016). Profil kesehatan republik indonesia 2015. Jakarta: Kementrian Kesehatan RI. (2015). Pedoman nasional penanganan infeksi menular seksual 2015. Jakarta: Kementerian Kesehatan RI

Keshinro B, Crowell TA, Nowak RG et al. (2016). High prevalence of HIV, chlamydia and gonorrhoea among men who have sex with men and transgender women attending trusted community centres in Abuja and Lagos, Nigeria. J Int AIDS Soc. 19(1):21270. doi: 10.7448/IAS.19.1.21270.

Ghanem KG, Quinn TC (2014). Sexually transmitted diseases. Reference Module in Biomedical Sciences. https://doi.org/10.1016/B978-0-12-8012383.02419-3

Kristina IP, Torsten B, Jakob B, Ronny T, Anna T, Birger F (2018). Place and practice: Sexual risk behaviour while travelling abroad among Swedish men who have sex with men. Travel Medi- cine and Infectious Disease. https://doi.org/10.1016/j.tmaid.2018.01.00 9.

Lutz AR (2015). Screening for asymptomatic extragenital gonorrhea and chlamydia in men who have sex with men: Significance, Recommendations, and Options for Overcoming Barriers to Testing. LGBT Health. 2(1): 27-34. doi: 10.1089/lgbt.2014.0056

Manurung RPR (2014). Analisis jalur (path analysisi): teori dan aplikasi dalam riset bisnis. Jakarta: Rineka Cipta.

María ÁPM, Esperanza CR, María TSO, Esperanza Castro-López, Francisco Jiménez-Bautista CHM (2017). Factores de riesgo relacionados con las infecciones de transmisión sexual. Revista Española de Salud Pública, 91: 1-6.

Martín MJ, Martínez JM, Rojas D (2011). Theory of planned behavior and risky sexual behavior in homosexual men. Rev Panam Salud Publica. 29(6):43343. PMID: 21829968

Matthew A (2015). Using the theory of planned behavior to determine the condom use behavior among college students. American Jornal of Health Studies. 30(1): 43-50.

Michael SK, Peter R.B, Billy H, Cordon-G, Amin SH (2018). Sexual health care practitioners' evaluation of men who have sex with men. The Journal of Sexual Medicine. 15(7): 942-946. Https://doi.org/10.1016/j.jsxm.2018.05.004 .

Morales A, Vallejo-MP, Abello-LD, et al. (2018). Sexual risk among Colombian adolescents: knowledge, attitudes, normative beliefs, perceived control, intention, and sexual behavior. BMC Public Health. 18(1):1377. doi: 10.1186/s12889-018-6311-y. 
Murti B (2017). Prinsip dan metode riset epidemiologi. Program Studi Ilmu Kesehatan Masyarakat, Program Pascasarjana Universitas Sebelas Maret. Surakarta

(2018). Prinsip dan Metode Riset Epidemiologi. Program Studi Ilmu Kesehatan Masyarakat, Program Pascasarjana Universitas Sebelas Maret. Surakarta.

(2018). Teori promosi dan perilaku kesehatan. Program Studi Ilmu Kesehatan Masyarakat, Program Pascasarjana Universitas Sebelas Maret. Surakarta.

Mustanski B, Feinstein BA, Madkins K, Sullivan P, Swann G (2017). Prevalence and risk factors for rectal and urethral sexually transmitted infections from self-collected samples among young men who have sex with men. Sex Transm Dis. 44(8): 483-488. doi: 10.1097/OLQ.0000000000000636.

Magnus U, Catriona SB, Jane SH, et al (2017). Sexually transmitted infections: challenges ahead. The Lancet Infectious Diseases, 17(8): e235-e279. https://doi.org/10.1016/S1473-3099(17)30310-9.

Ramadhani HO, Liu H, Nowak RG, et al (2017). Sexual partner characteristics and incident rectal Neisseria gonorrhoeae and Chlamydia trachomatis infections among gay men and other men who have sex with men (MSM): a prospective cohort in Abuja and Lagos, Nigeria. Sex Transm Infect. 93(5):348-355. doi: 10.1136/sextrans2016-052798.

Sarah R, Floyd BA, Pierce DM, Stephen AG (2016). Preventive and primary care of LGBT patients. The American Journal of Medical Science. http://dx.doi.org/10.1016/j.amjms.2016.05.008
Scott MH, Jeffrey DK (2016). Sexually transmitted infections and pre-exposure prophylaxis: Challenges and opportunities among men who have sex with men in the US. AIDS Research and Therapy. 13:5. Doi: 10.1186/s12981-016-0089-8.

Siahaan MSJ (2009). Perilaku menyimpang: Pendekatan Sosiologi. Jakarta: PT. Indeks.

Daili SF et al. (2017). Infeksi menular seksual. Jakarta: Badan Penerbit Fakultas Kedokteran Universitas Indonesia

Suleman ES (2016). Pembelajaran model dan teori perilaku kesehatan konsep dan aplikasi. Surakarta: Penerbitan dan Percetakan UNS (UNS Press)

Thoma BC, Huebner DM (2018). Parentadolescent communication about sex and condom use among young men who have sex with men: An Examination of the Theory of Planned Behavior. Ann Behav Med. 52(11):973-987. doi: 10.1093/abm/kayoo2.

World Health Organization (2015). Report on global sexually transmitted infection surveillance.

Yun Xian, Bowen Zhu, Xuan Zhang et al (2017). Risk factors associated with sexually transmitted infections among HIV infected men who have sex with men. PLoS ONE 12(2): e0170635. doi: 10.1371/journal.pone.0170635

Yusuf H, Kolliakou A, Ntouva A, Murphy M, Newton T, Tsakos G, Watt RG (2016). Predictors of dentists' behaviors in delivering prevention in primary dental care in England: Using The Theory of Planned Behavior. BMC Health Services Research. 16(44). Doi: 10.1186/s12913-016-1293-x. 